\title{
Increased Expression of Neuronal Nitric Oxide Synthase Spliced Variants in Reactive Astrocytes of Amyotrophic Lateral Sclerosis Human Spinal Cord
}

\author{
Maria Vincenza Catania, ${ }^{1}$ Eleonora Aronica, ${ }^{2}$ Bulent Yankaya, ${ }^{2}$ and Dirk Troost ${ }^{2}$ \\ 1/nstitute of Bioimaging and Pathophysiology of the Central Nervous System, National Research Council, 95123 Catania, \\ Italy, and 2Department of (Neuro)Pathology, Academic Medical Center, University of Amsterdam, 1105 AZ Amsterdam, \\ The Netherlands
}

\begin{abstract}
The expression of three different neuronal nitric oxide synthase (nNOS) spliced variants, named $\mathrm{nNOS} \alpha, \mathrm{nNOS} \beta$, and $\mathrm{nNOS} \gamma$, was investigated in the spinal cord of control and both familiar and sporadic amyotrophic lateral sclerosis (FALS and SALS) patients. Western blot analysis showed a consistent increase in nNOS expression in six SALS patients compared with controls when antibodies recognizing both $\mathrm{nNOS} \alpha$ and $\mathrm{nNOS} \beta$, or $\mathrm{nNOS} \alpha, \mathrm{nNOS} \beta$, and nNOS $\gamma$ were used, whereas no change was observed when a selective anti-nNOS $\alpha$ antibody was used. Immunoreactivity signal for $\mathrm{nNOS} \alpha-\beta-\gamma$ and $\mathrm{nNOS} \alpha-\beta$ was equally present in ventral horn neurons of control and ALS
\end{abstract}

Amyotrophic lateral sclerosis (ALS) is a neurological disease, whose cause is primarily unknown, that is characterized by loss of motor neurons and extensive astrogliosis in motor cortex and spinal cord (Eisen, 1995). Approximately 10-15\% of ALS cases are familiar. Mutations in the enzyme copper-zinc superoxide dismutase (SOD-1) have been identified, but they account only for one-fourth of all familiar ALS (FALS) cases.

Clinically and pathologically, FALS and sporadic ALS (SALS) are virtually identical, suggesting that there are common mechanisms of neurodegeneration. Glutamate-induced excitotoxicity and enhanced free radical and peroxynitrite production are considered the most relevant mechanisms leading to motor neuron degeneration (Brown, 1995). An increased protein nitration has been found in both SALS and FALS (Beal et al., 1997). An overproduction of nitric oxide (NO) with ensuing formation of peroxynitrite might induce the SOD-catalyzed tyrosine nitration of several proteins, including neurofilaments in motor neurons and glutamate transporters in glial cells (Beckman et al., 1993; Trotti et al., 1996).

An increased expression of neuronal NO synthase (nNOS) has been found recently in reactive astrocytes of transgenic mice overexpressing a human SOD-1 mutation (Gly-Ala at position 93) (Cha et al., 1998). Accordingly, AR-R 17,477, a novel highly selective nNOS inhibitor, significantly prolonged survival in the same G93A transgenic mouse model of FALS (Facchinetti et al.,

\footnotetext{
Received Jan. 17, 2001; revised March 9, 2001; accepted March 13, 2001.

This work was supported by Telethon-Italy Grant 1244 (M.V.C.). We thank W. P. Meun for expert photography, M. Cascone and H. Ijlst-Keizers for technical support, and Prof. F. Nicoletti for critically reading this manuscript.

M.V.C. and E.A. contributed equally to this work.

Correspondence should be addressed to Dr. Maria Vincenza Catania, Istituto di Bioimmagini e Fisiopatologia del Sistema Nervoso Centrale, Consiglio Nazionale delle Ricerche, Piazza Roma 2, 95123 Catania, Italy. E-mail: mcatania@ns.area.ct.cnr.it.

Copyright $(C) 2001$ Society for Neuroscience $0270-6474 / 01 / 210001-05 \$ 15.00 / 0$
}

spinal cord but was dramatically increased in reactive astrocytes of the ventral horn and white matter in both FALS and SALS. nNOS $\alpha$ signal was equally expressed in motor neurons of normal and ALS spinal cord but was not evident in astrocytes. This finding indicates that $\mathrm{nNOS} \beta$ and $\mathrm{nNOS} \gamma$ spliced variants are upregulated in reactive astrocytes in ALS. This may contribute to the peroxynitrite-mediated oxidative damage involved in the pathogenesis of both FALS and SALS.

Key words: amyotrophic lateral sclerosis; spinal cord; reactive astrocytes; nNOS; spliced variants; glia
1999). However, transgenic mice overexpressing the G93A mutated SOD-1 on nNOS null background do not live significantly longer than G93A mice (Facchinetti et al., 1999).

Recent work suggests that developmental- and tissue-specific nNOS expression is tightly regulated by a complex pattern of alternative splicing (Lee et al., 1997). Alternative splicing of nNOS gene gives rise to at least three different nNOS spliced transcripts, named $\mathrm{nNOS} \alpha, \mathrm{nNOS} \beta$, and $\mathrm{nNOS} \gamma \cdot \mathrm{nNOS} \alpha$ is the principal form, contains the exon 2, which carries a PDZ (postsynaptic density-95//Discs large/zona occludens-1) domain, and accounts for the great majority of NOS catalytic activity in the brain (Brenman et al., 1996). nNOS knock-out mice have a targeted deletion of nNOS exon 2, which disrupts nNOS $\alpha$ only. In these mice, $\mathrm{nNOS} \beta$ is upregulated by twofold to threefold, indicating that spliced forms other than $\mathrm{nNOS} \alpha$ may be important sources of NO (Eliasson et al., 1997). In the present study, we have investigated the expression of $\mathrm{nNOS} \alpha, \mathrm{nNOS} \beta$, and $\mathrm{nNOS} \gamma$ spliced forms in the spinal cord of control and both FALS and SALS patients, by using antibodies recognizing different epitopes located on the $\mathrm{NH}_{2}$ or $\mathrm{COOH}$ terminal regions of nNOS.

This article is published in The Journal of Neuroscience, Rapid Communications Section, which publishes brief, peerreviewed papers online, not in print. Rapid Communications are posted online approximately one month earlier than they would appear if printed. They are listed in the Table of Contents of the next open issue of JNeurosci. Cite this article as: JNeurosci, 2001, 21:RC148 (1-5). The publication date is the date of posting online at www.jneurosci.org.

http://www.jneurosci.org/cgi/content/full/5260 


\section{MATERIALS AND METHODS}

Subjects. Sections obtained at autopsy of the spinal cord of 26 patients were studied. Material was obtained from files of the Netherlands ALS tissue bank. Eighteen cases had clinical and postmortem neuropathological diagnoses of ALS (six female and six male SALS cases, and two female and four male FALS cases). The average age at onset was 54 years (range of 35-77), and the survival time from the onset of the disease varied between 7 and 326 months, with a mean of 48 months. Control spinal cord tissue was obtained from eight patients (five males and three females) who had died from a non-neurological disease (myocardial infarct, cancer, or pneumonia) with a mean age of 64 years (range of 41-87). All autopsies were performed within $12 \mathrm{hr}$ after death, and spinal cord tissues from the cervical (C7), thoracic (T4 and T8), and lumbar (L1) levels were collected. There were no significant differences between the different groups (SALS, FALS, and control) with respect to postmortem interval or duration of time storage.

Tissue preparation. Frozen tissue from five control and six SALS cervical spinal cords, stored at $-80^{\circ} \mathrm{C}$, was used for Western blot analysis. The six SALS cases used for Western blot were chosen among those having a strong astrogliosis as demonstrated by immunoreactivity (IR) against vimentin and glial fibrillary acid protein (GFAP). All specimens used for immunocytochemistry were fixed in formalin and embedded into paraffin. Immunocytochemistry was performed on sections from cervical, thoracic, and lumbar spinal cord from eight control, 12 SALS, and six FALS. Sections 5 - $\mu$ m-thick were cut on a sliding microtome and mounted on organosilane (3-aminopropylethoxysilane; Sigma, St. Louis, MO) coated slides. Representative sections of all specimens were processed for hematoxylin eosin and Nissl stains, as well as for immunocytochemical reactions using a number of neuronal and glial markers described below.

Antibodies. The following primary antibodies were used: polyclonal rabbit anti-neuron-specific enolase (1:10000; Sera-Lab, Sussex, UK), monoclonal mouse anti-GFAP (1:1000; Boehringer Mannheim, Mannheim, Germany), mouse monoclonal anti-vimentin (mouse clone V9; 1:400; Dako), mouse monoclonal anti-Tal1B5 neurofilament protein (HLA-DR; 1:100; Dako), mouse monoclonal anti $\beta$-actin (1:1000; Sigma), three polyclonal rabbit anti-nNOS [1:1000 (Transduction Laboratories, Lexington, KY), 1:500 (Chemicon, Temecula, CA), and 1:1000 (Santa Cruz Biotechnology, Santa Cruz, CA)], and one mouse monoclonal anti-nNOS (1:2000; Sigma). Two anti-nNOS antibodies, which were raised against a peptide corresponding to the amino acids sequence (1095-1289) of the human nNOS (brain-NOS, N31030; polyclonal rabbit; Transduction Laboratories) and against a peptide corresponding to the amino acids sequence (1414-1429) of the rat nNOS (brain-NOS, Ab1552; polyclonal rabbit; Chemicon), recognize epitopes located on the $\mathrm{COOH}$ terminal of nNOS sequence and are common to $\mathrm{nNOS} \alpha, \mathrm{nNOS} \beta$, and $\mathrm{nNOS} \gamma$. The peptide of the human nNOS was purchased from Transduction Laboratories (N53129). A third rabbit polyclonal antibody raised against a recombinant protein corresponding to amino acids 2-300 mapping at the $\mathrm{N}$ terminus of human nNOS recognizes both $\mathrm{nNOS} \alpha$ and $\mathrm{nNOS} \beta$ isoforms (NOS1 H-299; Santa Cruz Biotechnology). A fourth mouse monoclonal antibody raised against a recombinant neuronal NOS fragment (1-181) from rat brain recognizes nNOS $\alpha$ only (Sigma).

Western blot. For immunoblot analysis, tissue from human normal and ALS spinal cord were homogenized in lysis buffer containing $10 \mathrm{~mm}$ Tris, $\mathrm{pH} 8.0,150 \mathrm{~mm} \mathrm{NaCl}, 10 \%$ glycerol, $1 \% \mathrm{NP}-40,5 \mathrm{~mm}$ EDTA, and a cocktail of protease inhibitor (Boehringer Mannheim, Mannheim, Germany). Protein content was determined using the bicinchoninic acid method (Smith et al., 1985). Homogenate was diluted to a concentration of $3 \mathrm{mg}$ protein $/ \mathrm{ml}$ in SDS-bromophenol blue loading buffer and boiled for $5 \mathrm{~min}$. Equal amounts of proteins $(50 \mu \mathrm{g} / \mathrm{lane})$ were subjected to SDS-PAGE analysis in $7.5 \%$ gels. Separated proteins were transferred to nitrocellulose paper for $1 \mathrm{hr}$, using a semidry electroblotting system (Transblot SD; Bio-Rad, Hercules, CA), and incubated in TTBS $(50 \mathrm{~mm}$ Tris- $\mathrm{HCl}, 0.1 \%$ Tween 20, and $154 \mathrm{~mm} \mathrm{NaCl}, \mathrm{pH} 7.5$ ) containing 5\% nonfat dry milk and $1 \%$ bovine serum albumin (BSA) for $1 \mathrm{hr}$. Samples were then incubated over night in TTBS $-3 \%$ BSA-0.1\% sodium azide, containing the primary antibodies. After several washes in TTBS, the membrane were incubated in TTBS-5\% nonfat dry milk-1\% BSA containing the goat anti-rabbit or anti-mouse coupled to horse radish peroxidase (1:1500; Dako) for $2 \mathrm{hr}$. After several additional washes in TTBS, immunoreactive bands were visualized using an enhanced chemiluminescence kit (ECL; Amersham Pharmacia Biotech, Buckinghamshire, UK). In some cases (see Fig. $1 B$ ), $150 \mu \mathrm{g}$ of protein was loaded on a $8 \%$ polyacrylamide gel and probed with an anti-nNOS antibody (1:1000; Transduction Laboratories).

Immunocytochemistry. The sections were deparaffinated in xylene and, after rinses in ethanol (100 and 95\%), were incubated with $1 \% \mathrm{H}_{2} \mathrm{O}_{2}$ diluted in methanol for $20 \mathrm{~min}$. Slides were then washed with sodium PBS (10 mm sodium phosphate and $0.9 \% \mathrm{NaCl}, \mathrm{pH} 7.4)$. For vimentin, Tal1B5, and nNOS immunocytochemistry, the slides were placed into sodium citrate buffer $(0.01 \mathrm{M}, \mathrm{pH} 6.0)$ and heated in a microwave oven at $650 \mathrm{~W}$ for $10 \mathrm{~min}$. The slides were allowed to cool for $20 \mathrm{~min}$ in the same solution at room temperature (RT) and then washed in PBS. Afterward, they were incubated with a mixture of $10 \%$ normal goat serum, $0.1 \%$ gelatin, and 5\% BSA for $1 \mathrm{hr}$ before being incubated with primary antibodies for $30 \mathrm{~min}$ at RT and then $16 \mathrm{hr}$ at $4^{\circ} \mathrm{C}$. The sections were then washed thoroughly with PBS and incubated at RT for $1 \mathrm{hr}$ with the appropriate biotinylated secondary antibody diluted in PBS (1:400 goatanti rabbit Ig or 1:200 goat-anti mouse Ig; Dako). After washing in PBS, single-labeling immunocytochemistry was performed using the avidinbiotin peroxidase method (Vector Elite; Vector Laboratories, Burlingame, CA) and 3,3-diaminobenzidine as a chromogen. Sections were counterstained with hematoxylin, dehydrated in alcohol and xylene, and coverslipped. Sections incubated without the primary antibody or replacing it with preimmune sera were essentially blank.

Double-labeling immunocytochemistry was performed by incubating sections with anti-nNOS (Transduction Laboratories) and anti-vimentin (or anti-GFAP or anti-Tal1 B5) at the same time. After three washes in PBS, sections were then incubated for $1 \mathrm{hr}$ at RT with goat anti-rabbit Ig conjugate to peroxidase-labeled dextran polymer (Peroxidase; EnVision $^{+}$rabbit, ready to use; Dako) and 1:200 biotinylated goat anti-mouse (gam-BIO; Dako). After washes in PBS, sections were incubated for 45 min with a streptavidin-alkaline phosphatase complex (1:100 in PBS; Dako). Sections were then washed first with PBS and after with Tris-HCl buffer $(0.1 \mathrm{M}, \mathrm{pH} 8.5)$. The first chromogen used was Fast Blue B salt (2 $\mathrm{mg}$ in $0.1 \mathrm{~m}$ Tris- $\mathrm{HCl}$ buffer, $\mathrm{pH} 8.5$, containing $3 \mathrm{mg}$ of naphthol-ASMX-phosphoric acid and $1 \mathrm{~mm}$ levamidazole; Sigma). After washing, slides were stained with 3-amino-9-ethyl carbazole (Sigma). Sections were then washed with PBS, rinsed in distilled water, and mounted with glycerin-gelatin (Dako).

Evaluation of immunostaining. Both single- and double-labeled tissue sections from each type of immunocytochemical marker were examined by two observers with respect to the presence of specific immunoreactivity in glial cells and neurons. The immunostaining was rated, and a consensus score was obtained. We rated the degree of staining for nNOS on a semiquantitative four-point scale, in which immunoreactivity in glial cells was defined: $(-)$, not detectable; $(+)$, weakly positive; + , positive; ++ , intense; and +++ , very intense. Moreover, the frequency of nNOS immunopositive glial cells was assigned semiquantitatively to four categories: 1 , rare; 2 , sparse; 3 , high; and 4, very high.

\section{RESULTS \\ nNOS spliced variants $\beta$ and $\gamma$, but not $\alpha$, are upregulated in ALS spinal cord}

Western blot analysis with an anti-nNOS antibody (Transduction Laboratories) on total homogenates from human control cortex (data not shown) and spinal cord (Fig. 1A) showed a single band with a molecular weight of $\sim 155 \mathrm{kDa}$, which was not detectable in the presence of a specific blocking peptide (Fig. 1A). The nNOS-specific band (155 kDa) of ALS spinal cord appeared significantly denser than that of control (Figs. $1 A, 2)$. This result was obtained in all six SALS patients examined and was completely reproduced with a different antibody (Chemicon). These two antibodies initially used were both raised against epitopes located on the $\mathrm{COOH}$ terminal of the nNOS and recognize three different nNOS spliced variants named $\mathrm{nNOS} \alpha, \mathrm{nNOS} \beta$, and $\mathrm{nNOS} \gamma$. When $150 \mu \mathrm{g}$ protein/ lane rather than $50 \mu \mathrm{g}$ was loaded on a $8 \%$ polyacrylamide gel, Western blot analysis revealed three bands of slightly different molecular weight, likely corresponding to the human $\mathrm{nNOS} \alpha$, $\mathrm{nNOS} \beta$, and nNOS $\gamma$. The upper band (NOS $\alpha$ ) showed a similar density in control and ALS, whereas the lower bands were 

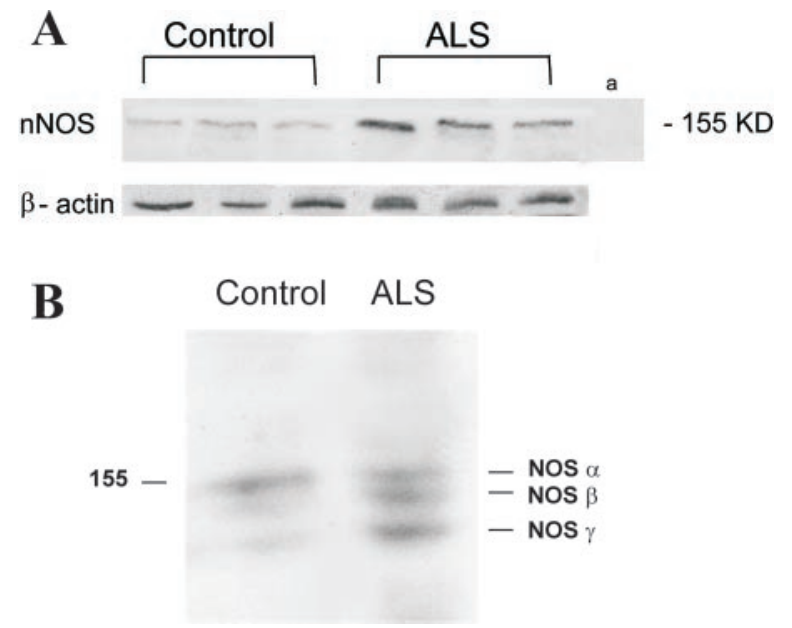

Figure 1. Expression of nNOS in total homogenates from control and SALS spinal cord. $A$, Western blot with an anti-NOS antibody (Transduction Laboratories) reveals a single band of $155 \mathrm{kDa}$, which has a higher density in SALS compared with control and is not evident in the presence of the immunogenic peptide $(a)$. A Western blot on proteins from the same patients revealed no change in the amount of $\beta$-actin in SALS compared with control. Proteins $(50 \mu \mathrm{g} /$ lane $)$ from three control and three patients were loaded. $B$, A Western blot with the same antibody under different experimental conditions $(150 \mu \mathrm{g} /$ lane protein; $8 \%$ polyacrylamide gel) reveals the presence of three bands likely corresponding to the human nNOS spliced variants $\mathrm{nNOS} \alpha, \mathrm{nNOS} \beta$, and $\mathrm{nNOS} \gamma$. The band with the highest molecular weight had similar density in control and ALS, whereas the bands with a lighter molecular weight had a higher density in ALS than control.

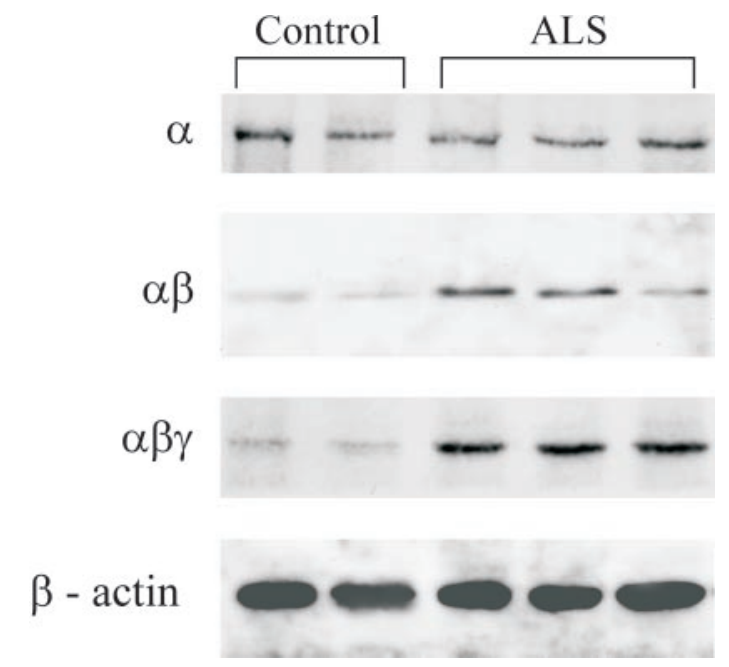

Figure 2. nNOS upregulation is detectable with antibodies that recognize $\mathrm{nNOS} \alpha-\beta$ and $\mathrm{nNOS} \alpha-\beta-\gamma$ but not $\operatorname{nNOS} \alpha$. Protein $(50 \mu \mathrm{g} /$ lane) from two control and three SALS, different from in Figure 1, were loaded in each lane.

definitively denser in ALS than control (Fig. 1B). This result suggested that $\mathrm{nNOS} \alpha$, the prominent nNOS splice variant in control spinal cord, was unchanged in ALS, whereas NOS $\beta$ and NOS $\gamma$ were upregulated in ALS spinal cord. This was confirmed in a different set of Western blot experiments showing that nNOS resulted as equally expressed in control and ALS patients when a specific anti-nNOS $\alpha$ (Sigma) was used, whereas it was upregulated when an anti-nNOS $\alpha-\beta$ or an anti-nNOS $\alpha-\beta-\gamma$ antibody was used (Fig. 2).

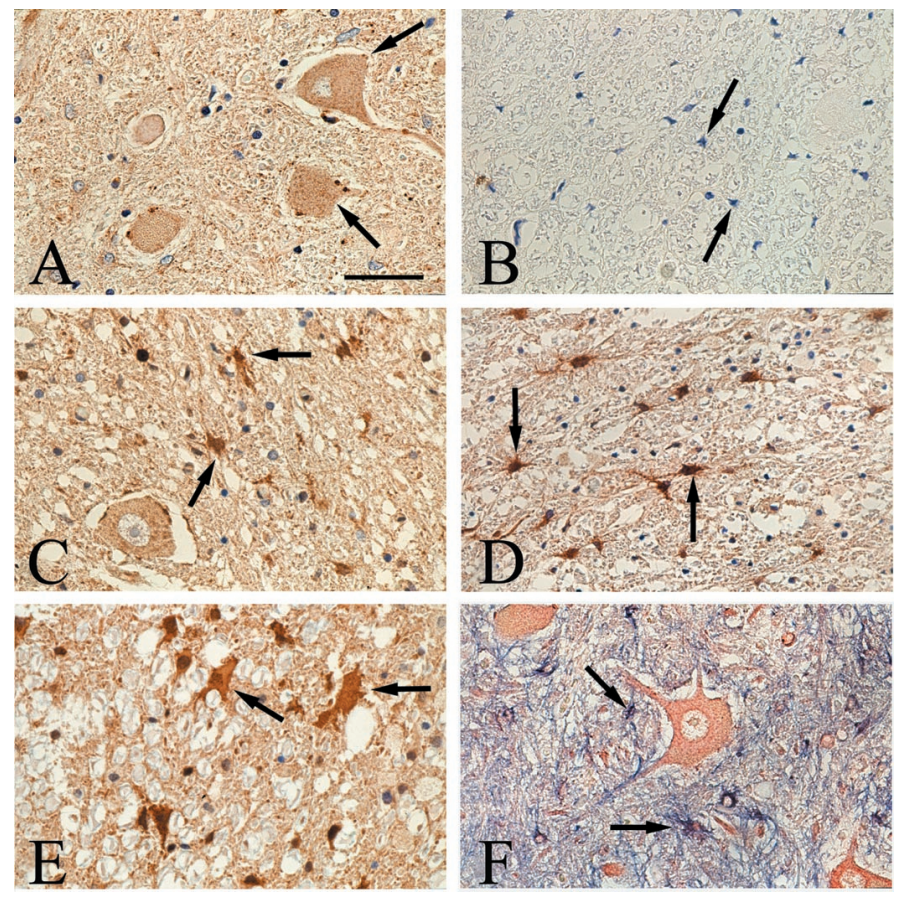

Figure 3. Distribution of nNOS immunoreactivity in cervical spinal cord from controls $(A, B)$ or ALS patients $(C-E) . F$, Colocalization with vimentin in reactive astrocytes. $A$ shows control ventral horn. Motor neurons in lamina IX (arrows) are positive for nNOS. $B$ shows control corticospinal tract with unstained glial cells (arrows). In ALS ventral horns $(C)$, a substantial increase in nNOS immunoreactivity appears in astrocytes (arrows). $D$ and $E$ show ALS corticospinal tract of two patients with intensively stained glial cells (arrows); both fibrillary $(D)$ and protoplasmic astrocytes $(E)$ are strongly labeled with nNOS antibodies. $F$ shows colocalization (purple) of nNOS (red) with vimentin (blue) in reactive astrocytes (arrows) in ALS ventral horn. Scale bar, $105 \mu \mathrm{m}$.

\section{$\mathrm{nNOS} \beta$ and $\mathrm{nNOS} \gamma$ are upregulated in reactive astrocytes in ALS spinal cord}

Immunocytochemistry was performed to study the cellular distribution of different nNOS isoforms in normal and ALS spinal cord by using two anti-nNOS $\alpha-\beta-\gamma$, an anti-nNOS $\alpha-\beta$ and an anti-nNOS $\alpha$. In agreement with previous studies (Chou et al., 1996; Wong and Strong, 1998), immunolabeling for nNOS was observed in both control and ALS (FALS and SALS) motor neurons (Fig. $3 A, C$ ) with all antibodies. No detectable difference was observed in the labeling pattern and intensity of nNOS in either ventral and medial populations of ALS motor neurons when compared with control neuronal populations from cervical, thoracic, and lumbar levels. In the majority of control spinal cord specimens, no nNOS-IR was detectable in astrocytes of the ventral horn, whereas in the white matter only weakly positive rare glial cells were observed (Fig.3A,B; Table 1).

In the spinal cord of both SALS and FALS, immunocytochemistry showed in all specimens an abundant population of intensively stained nNOS-IR glial cells with the anti-nNOS $\alpha-\beta-\gamma$ and anti-nNOS $\alpha-\beta$, but not with the anti-nNOS $\alpha$, antibodies. In the cervical segments, nNOS-IR glial cells were observed in ventral horns, as well as in the white matter, in which they were particularly represented in the anterolateral tracts (Fig.3C-E; Table 1). The distribution of nNOS-IR glial cells was similar in the thoracic and lumbar segments and reflected the presence of reactive astrocytes, as suggested by their morphological features (Fig. $3 C-E)$. Accordingly, all cases included in the study showed prom- 


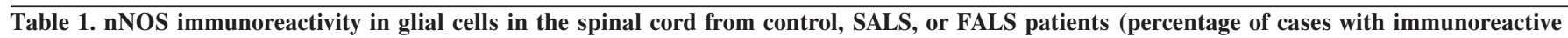
cells)

\begin{tabular}{|c|c|c|c|c|c|c|c|c|c|c|c|c|c|c|c|}
\hline \multirow{3}{*}{$\begin{array}{l}\text { nNOS immuno- } \\
\text { reactivity in glial } \\
\text { cells }\end{array}$} & \multicolumn{5}{|c|}{ Control (8) } & \multicolumn{5}{|c|}{ SALS (12) } & \multicolumn{5}{|c|}{ FALS (6) } \\
\hline & \multicolumn{4}{|c|}{ Intensity } & \multirow{2}{*}{$\frac{\text { Frequency }}{1-4}$} & \multicolumn{4}{|c|}{ Intensity } & \multirow{2}{*}{$\frac{\text { Frequency }}{1-4}$} & \multicolumn{4}{|c|}{ Intensity } & \multirow{2}{*}{$\frac{\text { Frequency }}{1-4}$} \\
\hline & $(+)$ & + & ++ & +++ & & $(+)$ & + & ++ & +++ & & $(+)$ & + & ++ & +++ & \\
\hline Ventral horns & $25 \%$ & - & - & - & (1) & - & $8 \%$ & $42 \%$ & $50 \%$ & $(2-3)$ & $17 \%$ & $33 \%$ & $50 \%$ & - & $(1-2)$ \\
\hline White matter & $63 \%$ & $25 \%$ & - & - & $(1-2)$ & - & $9 \%$ & $33 \%$ & $58 \%$ & $(3-4)$ & - & - & $17 \%$ & $83 \%$ & $(3-4)$ \\
\hline
\end{tabular}

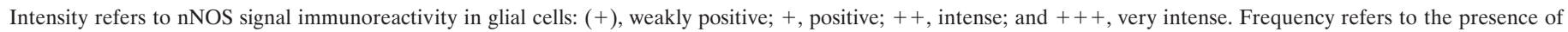

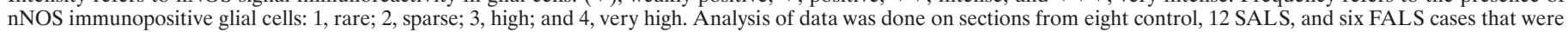

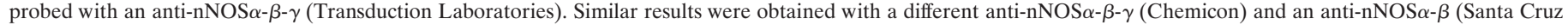
Biotechnology).

inent astrogliosis, which was detected using glial markers such as GFAP or another intermediate filament protein, vimentin, which allowed the detection of selective populations of reactive hypertrophic astrocytes (Khurgel et al., 1996). Blocking peptide of human nNOS abolished $\mathrm{nNOS} \alpha-\beta-\gamma$-IR in neurons and astrocytes of both control and ALS specimens (data not shown). Double-labeling with vimentin confirmed the $\mathrm{nNOS} \alpha-\beta-\gamma$ expression in reactive astrocytes (Fig. $3 F$ ). Because vimentin could be present in activated microglia and macrophages (Graeber et al., 1988) and pronounced microglia activation was observed in ALS spinal cord, we performed a double-labeling with the microglia indicator Tal1B5. The double-labeling showed that Tal1B5positive microglial cells do not express detectable nNOS-IR (data not shown).

\section{DISCUSSION}

The present study provides evidence for a consistent upregulation of nNOS in reactive astrocytes in both SALS and FALS. The increased nNOS expression in ALS was observed by Western blotting with antibodies recognizing $\mathrm{nNOS} \alpha-\beta-\gamma$ and $\mathrm{nNOS} \alpha-\beta$ but not nNOS $\alpha$. This result was confirmed by immunocytochemistry by using the same antibodies, suggesting that the $\beta$ and $\gamma$ nNOS isoforms are selectively upregulated in ALS. Doublelabeling experiments revealed that this upregulation occurs in reactive astrocytes but not in microglia. Although initially thought as a merely constitutive enzyme, nNOS induction has been widely demonstrated in neurons both in vitro and in vivo (Verge et al., 1992; Wu et al., 1994; Estévez et al., 1998). Our results support the view that nNOS expression might be dynamically regulated through the use of multiple alternative promoters, as well as alternative splicing in non-neuronal cells (Lee et al., 1997).

Our report is in line with previous results showing an increased expression of nNOS in reactive astrocytes in G93A-SOD1 transgenic mice with a anti nNOS $\alpha-\beta-\gamma$ antibody (Cha et al., 1998) but no change with a different antibody, which recognizes only the NOS $\alpha$ isoform (Almer et al., 1999). The possibility that nNOS $\beta$ and nNOS $\gamma$ isoforms were selectively upregulated in reactive astrocytes of G93A mice was postulated by Almer and collaborators to explain this apparent discordant result. In the present study, we proved this speculation to be correct in ALS patients. The selective nNOS $\beta$ and/or nNOS $\gamma$ upregulation might explain why disruption of $\mathrm{nNOS} \alpha$ has no beneficial effect in G93A mice (Facchinetti et al., 1999) and suggests a role for these two isoenzymes in the pathogenesis of ALS. Interestingly, nNOS present in cultured astroglia is totally soluble and might be a variant such as $\mathrm{nNOS} \beta$ and/or nNOS $\gamma$ lacking the PDZ domain, which anchor nNOS to membrane-associated proteins (Arbonés et al., 1996).
The presence of an nNOS variant similar to $\mathrm{nNOS} \beta$ has been found in many brain tumors, suggesting that this nNOS spliced variant might be relevant in human pathology (Brenman et al., 1997).

We observed that nNOS is constitutively expressed in motor neurons and noted no apparent difference in the level of protein expression between ALS and controls in motor neurons. This result was obtained with all the antibodies used in our study. Others have reported previously that nNOS is constitutively expressed in human motor neurons by radioactive in situ hybridization, but they have not noticed any increased signal in neurons or astrocytes of ALS patients (Wong and Strong, 1998). The in situ probe used by these authors recognized exons 14 to 20 of the human gene, which are common to $\mathrm{nNOS} \alpha, \mathrm{nNOS} \beta$, and nNOS $\gamma$. It is possible that the radioactive in situ hybridization method used by these authors did not allow to detect any increased grain density in astrocytes, but it is also conceivable that nNOS is post-transcriptionally regulated in astrocytes. Other authors have described an increased expression of nNOS in motor neurons of ALS patients (Chou et al., 1996; Abe et al., 1997), which was not evident in our study. Although we did not observe any apparent difference in the expression level of nNOS in surviving motor neurons of controls and ALS, we did not systematically focus on motor neurons. Thus, we cannot exclude that a slight modification in nNOS expression in degenerating soma and axons of motor neurons might occur in ALS.

An increased protein nitration has been found in both SALS and FALS (Beal et al., 1997), and our findings suggest that a glial production of NO is a pathogenic factor common to both forms of ALS. An aberrant nitration of glial glutamate transporters might contribute to the increased glutamate levels, which would ultimately lead to motor neuron death via an excitotoxic mechanism (Trotti et al., 1996). In addition, the highly diffusible NO produced in astrocytes can directly cause damage to mitochondrial respiratory chain of neighboring neurons (Heales et al., 1999) and might participate in nitration and ensuing inactivation of neuronal proteins. Accordingly, an increased expression of nNOS-IR (with an antibody raised against the $\mathrm{C}$-terminal region of rat nNOS) in reactive astrocytes has been found to correlate with the amount of cell death in Alzheimer's disease, suggesting that NO released by glial cells might contribute to neuronal degeneration in different pathological conditions (Šimić et al., 2000)

nNOS is a $\mathrm{Ca}^{2+} /$ calmodulin-dependent enzyme (Nathan and $\mathrm{Xie}, 1994)$. Its increased expression in ALS spinal cord raises the question of how the enzyme is activated in reactive astrocytes. $\mathrm{Ca}^{2+}$-permeable AMPA receptors and metabotropic glutamate receptors (mGluRs) coupled to inositol phospholipid hydrolysis 
(mGlu1 and mGlu5) are present in glial cells (Burnashev et al., 1992; Miller et al., 1995). Activation of these receptors by the elevated extracellular glutamate may contribute to the activation of glial nNOS in ALS. Accordingly, we have found recently an increased expression of mGlu1 and mGlu5 receptor subtypes in reactive astrocytes of ALS spinal cord (Aronica et al., 2001). The amount of NO released from astrocytes might further enhance extracellular glutamate through the nitration of the glutamate transporters, thus generating a vicious cycle that ultimately results into motor neuron degeneration.

\section{REFERENCES}

Abe K, Pan LH, Watanabe M, Konno H, Kato T, Itoyama Y (1997) Upregulation of protein-tyrosine nitration in the anterior horn cells of amyotrophic lateral sclerosis. Neurol Res 19:124-128.

Almer G, Vukosavic S, Romero N, Przedborski S (1999) Inducible nitric oxide synthase up-regulation in a transgenic mouse model of familial amyotrophic lateral sclerosis. J Neurochem 72:2415-2425.

Aronica E, Catania MV, Geurts J, Yankaya B, Troost D (2001) Immunohistochemical localization of Group I and II metabotropic glutamate receptors in control and ALS human spinal cord: upregulation in reactive astrocytes. Neuroscience, in press.

Arbonés ML, Ribeira J, Agullo L, Baltrons MA, Casanovas A, RiverosMoreno V, Garcia A (1996) Characteristics of nitric oxide synthase type-I of rat cerebellar astrocytes. Glia 18:224-232.

Beal MF, Ferrante RF, Browne SE, Matthews RT, Kowall NW, Brown RH (1997) Increase 3-nitrotyrosine in both sporadic and familial amyotrophic lateral sclerosis. Ann Neurol 42:646-654.

Beckman JS, Carson M, Smith CD, Koppenol WH (1993) ALS, SOD and peroxynitrite. Nature 364:584.

Brenman JE, Chao DS, Gee SH, McGee AW, Craven SE, Santillano DR, Wu Z, Huang F, Xia H, Peters MF, Foehner SC, Bredt DS (1996) Interaction of nitric oxide synthase with the postsynaptic density protein PSD-95 and a1-syntrophin mediated by PDZ domains. Cell 84:757-767.

Brenman JE, Xia H, Chao DS, Black SM, Bredt DS (1997) Regulation of neuronal nitric oxide synthase though alternative transcripts. Dev Neurosci 19:224-231.

Brown Jr RH (1995) Amyotrophic Lateral Sclerosis: recent insight from genetic and transgenic mice. Cell 80:687-692.

Burnashev N, Khodorova A, Jonas P, Helm PJ, Wisden W, Monyer H, Seeburg PH, Sakmann B (1992) Calcium permeable AMPA receptors in fusiform cerebellar glial cells. Science 256:1566-1570.

Cha IC, Kim J-M, Shin DH, Kim YS, Kim J, Gurney ME, Lee KW (1998) Reactive astrocytes express nitric oxide synthase in the spinal cord of transgenic mice expressing a human $\mathrm{Cu} / \mathrm{Zn}$ SOD mutation. NeuroReport 9:1503-1506.

Chou SM, Wang HS, Komai K (1996) Colocalization of NOS and SOD1 in neurofilament accumulation within motor neurons of amyotrophic lateral sclerosis: an immunohistochemical study. J Chem Neuroanat 10:249-258.

Eisen A (1995) Amyotrophic lateral sclerosis is a multifactorial disease. Muscle Nerve 18:741-752.

Eliasson MJL, Blackshaw S, Schell MJ, Snyder SH (1997) Neuronal nitric oxide synthase alternatively spliced forms: prominent functional localizations in the brain. Proc Natl Acad Sci USA 94:3396-3401.

Estévez AG, Spear N, Manuel SM, Radi R, Henderson CE, Barbeito L, Beckman JS (1998) Nitric oxide and superoxide contribute to motor neuron apoptosis induced by trophic factor deprivation. J Neurosci 18:923-931.

Facchinetti F, Sasaki M, Cutting FB, Zhai P, MacDonald JE, Reif D, Beal MF, Huang PL, Dawson TM, Gurney ME, Dawson VL. (1999) Lack of involvement of neuronal nitric oxide synthase in the pathogenesis of a transgenic mouse model of Familial Amyotrophic Lateral Sclerosis. Neuroscience 90:1483-1492.

Graeber MB, Streit WJ, Kreutzberg GW (1988) The microglia cytoskeleton: vimentin is localized within activated cells in situ. J Neurocytol 17:573-580.

Heales SJ, Bolanos JP, Stewart VC, Brookes PS, Land JMN, Clark JB (1999) Nitric oxide, mitochondria and neurological disease. Biochim Biophys Acta 1410:215-228.

Khurgel M, Switzer III RC, Teskey GC, Spiller AE, Racine RJ, Ivy GO (1996) Activation of astrocytes during epileptogenesis in the absence of neuronal degeneration. Neurobiol Dis 2:23-35.

Lee MA, Cai L, Hübner N, Lee YA, Lindpainter K (1997) Tissue- and development-specific expression of multiple alternatively spliced transcript of rat neuronal nitric oxide synthase. J Clin Invest 100:1507-1512.

Miller S, Romano C, Cotman CW (1995) Growth factor upregulation of a phosphoinositide-coupled metabotropic glutamate receptor in cortical astrocytes. J Neurosci 15:6103-6109.

Nathan C, Xie Q-W (1994) Regulation of biosynthesis of nitric oxide. J Biol Chem 269:13725-13728.

Šimić G, Lucassen PJ, Krsnic Z, Krušlin B, Kostovic I, Winblad B, Bogdanovic N (2000) nNOS expression in reactive astrocytes correlates with increased cell death related DNA damage in the hippocampus and entorhinal cortex in Alzheimer's disease. Exp Neurol 165:12-26.

Smith PK, Krohn RI, Hermanson GT, Mallia AK, Gertner FH, Provenzano MD, Fujimoto NM, Olson BJ, Klenk DC (1985) Measurement of protein using bicinchoninic acid. Anal Biochem 150:76-85.

Trotti D, Rossi D, Gjesdal O, Levy LM, Racagni G, Danbolt NC, Volterra A (1996) Peroxynitrite inhibits glutamate transporter subtypes. J Biol Chem 271:5976-5979.

Verge VM, Xu Z, Xu XJ, Wiesenfeld-Hallin Z, Hokfelt T (1992) Marked increase in nitric oxide synthase mRNA in rat dorsal root ganglia after peripheral axotomy: in situ hybridization and functional studies. Proc Natl Acad Sci USA 89:11617-11621.

Wong NKY, Strong MJ (1998) Nitric oxide synthase expression in cervical spinal cord in sporadic amyotrophic lateral sclerosis. Eur J Cell Biol 77:338-343.

Wu W, Liuzzi FG, Schinco FP, Depto AS, Li Y, Mong JA, Dawson TM, Snyder SH (1994) Neuronal nitric oxide is induced in spinal cord by traumatic injury. Neuroscience 4:719-726. 